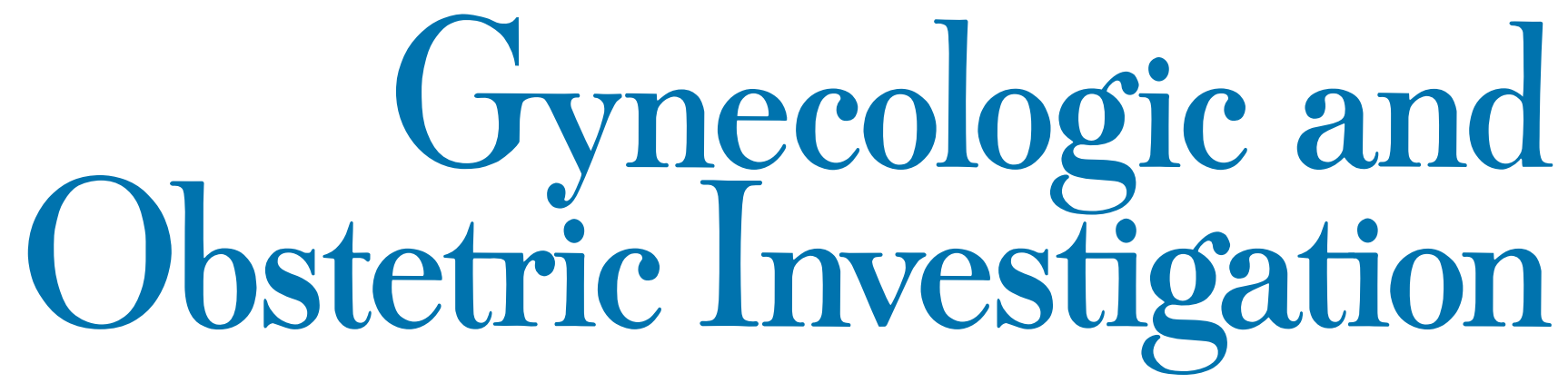

Original Articles

177 DFF45 Expression in Human Endometrium Is Associated with Menstrual Cycle Phases and Decreases after Menopause

Banas, T.; Basta, P.; Knafel, A.; Skotniczny, K.; Jach, R.; Hajdyla-Banas, I.; Grabowska, O. (Krakow)

183 Thrombophilia among Chinese Women with Venous Thromboembolism during Pregnancy

Tam, W.-H.; Ng, M.H.-L.; Yiu, A.K.-W.; Lau, K.-M.;

Cheng, G.Y.-M.; Li, C.-Y. (Hong Kong)

189 The Effects of Epidermal Growth Factor and Transforming Growth Factor- $\alpha$ on Secretion of Interleukin-8 and Growth-Regulated Oncogene- $\alpha$ in Human Granulosa-Lutein Cells

Kawano, Y.; Zeineh, K.; Furukawa, Y.; Utsunomiya, Y.; Okamoto, M.; Narahara, H. (Oita)

195 Does Vaginal Irrigation with Saline Solution in Women with Infectious Vaginitis Contribute to the Clinical and Microbiological Results of Antibiotic Therapy? Derbent, A.U.; Ulukanlıgil, M.; Keskin, E.A.; Soylu, G.; Kafalı, H. (Ankara)

201 Effect of Preeclampsia Serum on Human Uterine Spiral Artery Smooth Muscle Cell Apoptosis in a Coculture Model with Cytotrophoblasts

Jiang, R.; Yan, S.; Teng, Y.; Huang, Y.; Gu, J.; Li, M. (Shanghai)

211 A Thai Reference for Normal Fetal Nasal Bone Length at 11-13(+6) Weeks Gestation

Pruksanusak, N.; Suwanrath, C.; Kor-anantakul, O.;

Suntharasaj, T.; Hanprasertpong, T.; Pranpnus, S.; Geater, A.F. (Hat Yai)

217 Predicting the Route of Delivery in Women with LowLying Placenta Using Transvaginal Ultrasonography: Significance of Placental Migration and Marginal Sinus

Ohira, S.; Kikuchi, N.; Kobara, H.; Osada, R.; Ashida, T.; Kanai, M.; Shiozawa, T. (Matsumoto)
223 The Immunoprotective Role of Interleukin-10 in Abnormal Pregnancy Outcome Induced by Toxoplasma gondii Infection

Zhang, R.; Zhang, H.; Liu, X.; Fu, Q.; Xu, X.; Hu, X. (Yantai)

230 Thermal Artifact after Three Techniques of Loop Excision of the Transformation Zone: A Comparative Study

Boonlikit, S.; Yanaranop, M. (Bangkok)

236 Expression Levels of Vascular Cell Adhesion Molecule-1 in Young and Nonobese Women with Polycystic Ovary Syndrome

Seow, K.-M.; Juan, C.-C.; Wang, P.-H.; Ho, L.-T.; Hwang, J.-L. (Taipei)

242 Comparison of Low-Dose Oxytocin and Dinoprostone for Labor Induction in Postterm Pregnancies: A Randomized Controlled Prospective Study Akay, N.Ö.; Hızlı, D.; Yılmaz, S.S.; Yalvaç, S.; Kandemir, Ö. (Ankara)

248 Levels of Heat Shock Protein 27 in Placentae from Small for Gestational Age Newborns

Cañete, P.; Monllor, A.; Pineda, A.; Hernández, R.; Tarín, J.J.; Cano, A. (Valencia)

252 Alpha-1-Antitrypsin Acts as a Preeclampsia-Related Protein: A Proteomic Study

Feng, Y.-L. (Shenzhen/Changsha/Guangzhou); Zhou, C.-J. (Changsha); Li, X.-M. (Guangzhou); Liang, X.-Q. (Shenzhen)

Novel Insights from Clinical Practice

260 Uterine Inversion in Association with Uterine Sarcoma: A Case Report with MRI Findings and Review of the Literature

Occhionero, M.; Restaino, G.; Ciuffreda, M.; Carbone, A.; Sallustio, G.; Ferrandina, G. (Campobasso)

\footnotetext{
S. Karger
Medical and Scientific Publishers Basel $\cdot$ Freiburg $\cdot$ Paris . London - New York . New Delhi $\cdot$ Bangkok $\cdot$ Beijing Tokyo Kuala Lumpur . Singapore $\cdot$ Sydney
} 


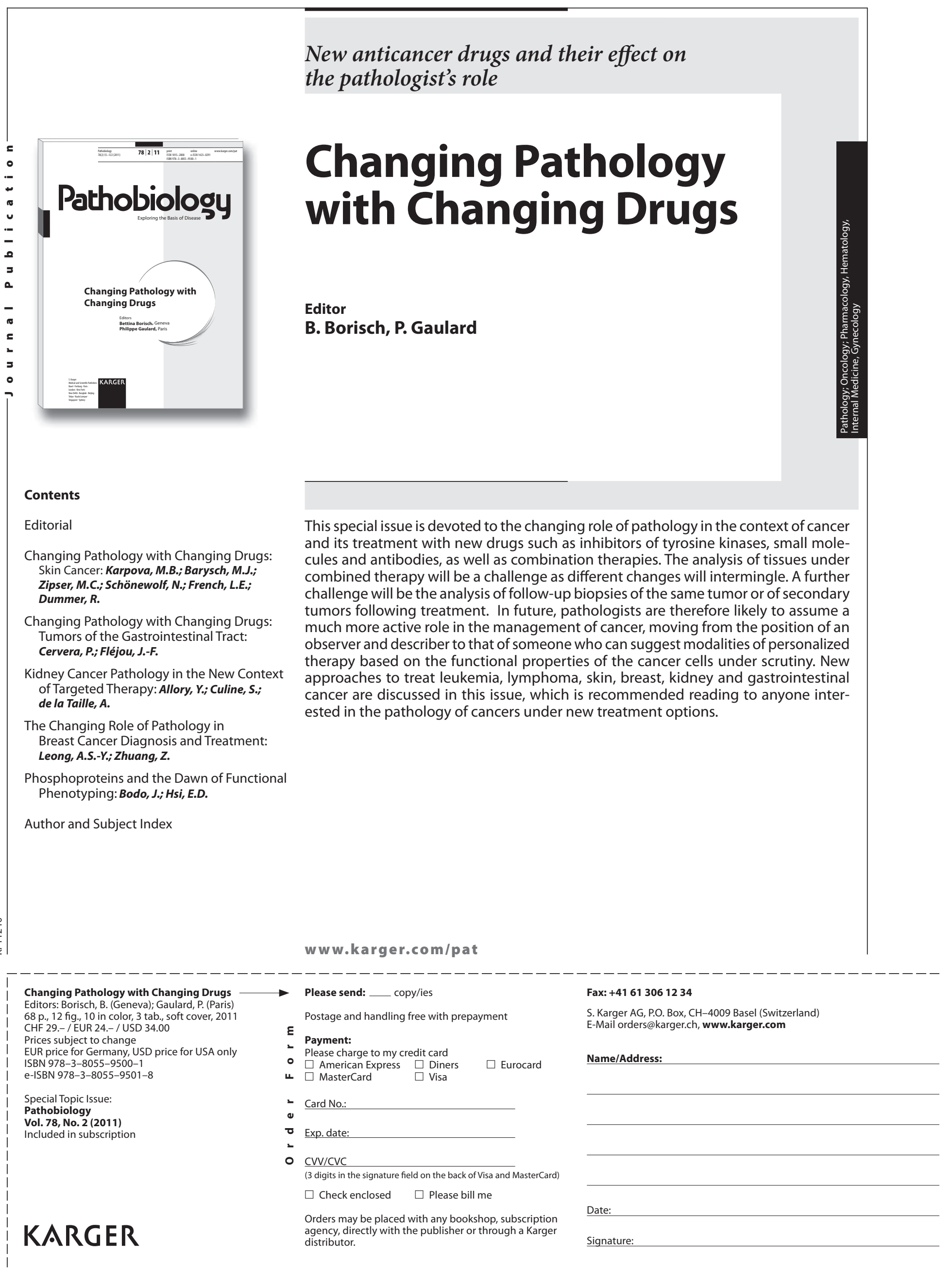




\section{Gynecologic and
etric Investigation}

Founded 1895 as 'Monatsschrift für Geburtshilfe und Gynäkologie', continued 1946-1969 as 'Gynaecologia' and 1970-1977 as 'Gynecologic Investigation'

\section{Editor-in-Chief}

T.M. D’Hooghe, Leuven
Founders: A. Martin and M. Sänger

Former Editors: E. Anderes (1939-1952), Th. Koller (1939-1969), O. Käser (1954-1969),

R. Wenner (1959-1967), P. Bloch (1965-1969), W.L. Hermann (1970-1975),

P.J. Keller (1976-1984), G. Zador (1985-2001), J. Yankowitz (2002-2005)

\section{Associate Editors}

Benign Gynecological Diseasel

Gynecological Surgery

A.D. Ebert, Berlin

Clinical Obstetrics

Edgar Hernandez-Andrade,

Detroit, Mich.

Early Pregnancy and

Recurrent Miscarriage

Ole B. Christiansen, Copenhagen

Fetal Medicine/Surgery

Roland De Vlieger, Leuven

Gynecologic Oncology

Christina Bandera, Cranston, R.I.
Gynecological Ultrasound and Imaging

George Condous, Sydney, N.S.W.

Infectious Diseases

Gilbert G.G. Donders, Leuven

Menopause, Contraception and

General Gynecologic Endocrinology

Serge Rozenberg, Brussels

Prenatal Diagnosis

Waldo Sepulveda, Santiago

Psychology, Sexuology and

Mental Health

Jacky Boivin, Cardiff

Reproductive Genetics

Zi-Jiang Chen, Jinan
Reproductive Immunology

Aydin Arici, New Haven, Conn.

Reproductive Surgery

Togas Tulandi, Montreal, Que.

Society/Ethics/History

I. D. Cooke, Sheffield

Urogynecology

Jan-Paul Roovers, Amsterdam

\section{Editorial Board}

\section{M.A. Belfort, Provo, Utah}

J. Bornstein, Nahariya

H.L. Brown, Durham, N.C.

C. Chapron, Paris

J. de Haan, Maastricht

G.A. Dekker, Adelaide, S.A.

J.A. Deprest, Leuven

K. Hecher, Hamburg

S. Kahhale, São Paulo

H. Kliman, New Haven, Conn.
T.F. Kruger, Tygerberg

J.A. Kuller, Raleigh, N.C.

M.J. Kupferminc, Tel Aviv

H. Minkoff, Brooklyn, N.Y.

J. Moodley, Congella

J.M. Mwenda, Nairobi

H. Odendaal, Tygerberg

J.T. Repke, Hershey, Pa.

G.R. Saade, Galveston, Tex.

B.M. Sibai, Cincinnati, Ohio
S.K. Smith, London

I.E. Timor-Tritsch, New York, N.Y.

S. Uzan, Paris

Johan Verhaeghe, Leuven

J.J. Walker, Leeds

G.D. Wendel, Dallas, Tex.

R.A. Wild, Oklahoma City, Okla.

G. Zador, Södertälje

M.B. Zimmerman, Iowa City, Iowa
Printed in Switzerland on acid-free and non-aging paper (ISO 9706) by

Reinhardt Druck, Basel
Appears 6-weekly: 2 volumes per year (8 issues) 


\section{Gynecologic and Obstetric Investigation}

\section{Submission}

Manuscripts written in English should be submitted using the online submission website at:

\section{www.karger.com/goi}

or as e-mail attachment (the preferred word-processing package is MS-Word) to the Editorial Office:

\section{goi@karger.ch \\ Profs. T.M. D'Hooghe \\ S. Karger AG \\ Editorial Office 'Gynecologic and \\ Obstetric Investigation' \\ P.O. Box \\ CH-4009 Basel (Switzerland) \\ Tel. +41613061344 \\ Fax +41613061434 \\ E-Mail s.aeschbach@karger.ch}

The manuscripts should be accompanied by a signed copyright transfer statement (please see submission website). Names, postal and e-mail addresses of four experts in the appropriate area of research should accompany each manuscript. Referees suggested should not be from the same institute as the authors and, preferably, not from the same country.

Presentation of manuscripts should conform with the Uniform Requirements for Manuscripts Submitted to Biomedical Journals (see N Engl J Med 1997;336:309315).

\section{Conditions}

All manuscripts are subject to editorial review. Submission of an article for publication implies the transfer of the copyright from the author to the publisher upon acceptance. Accepted papers become the permanent property of 'Gynecologic and Obstetric Investigation' and may not be reproduced by any means, in whole or in part, without the written consent of the publisher. It is the author's responsibility to obtain permission to reproduce illustrations, tables, etc. from other publications.

Cover letter: All manuscripts must be accompanied by a covering letter signed by all authors.

Assurance should be given that the manuscript is not under simultaneous consideration by any other publication.

All manuscripts originating from non-Englishspeaking countries must be revised by a professional linguistic reviewer and it must be evident from the covering letter that this has been done.

Names, postal and e-mail addresses of four experts in the appropriate area of research should accompany each manuscript. Referees suggested should not be from the same institution as the author.

Good clinical practice: It has become mandatory that every trial in humans must first obtain approval from an independent Ethics Committee and formal, informed consent from the patients before they participate in a clinical study or experiment. In order to avoid unnecessary delay with the review of manuscripts, authors are asked to state, preferably in the Materials and Methods section, that approval and informed consent have been obtained. These two statements must also appear on the covering letter which accompanies every manuscript and is signed by each author.

\section{Arrangement}

All pages should be consecutively numbered beginning with the title page, then the text, acknowledgements, references and legends to figures. The text in original papers should be divided under the headings: Abstract, Introduction, Material(s) and Method(s), Results, and Discussion.

Title page: The first page of each paper should indicate the title, the authors' names, the institute where the work was conducted, and a short title for use as running head.

Full address: The exact postal address of the corresponding author complete with postal code must be given at the bottom of the title page. Please also supply phone and fax numbers, as well as e-mail address.

Key words: For indexing purposes, a list of 3-10 key words in English is essential.

Abstract: Each paper needs an abstract of up to 200 words. It should be structured as follows:

Background/Aims: What is the major problem

$\begin{array}{ll} & \text { that prompted the study? } \\ \text { Methods: } & \text { How was the study performed? } \\ \text { Results: } & \text { Most important findings? }\end{array}$

Most important findings?

Conclusion: Most important conclusion?

Footnotes: Avoid footnotes. When essential, they are numbered consecutively and typed at the foot of the appropriate page.

Tables and illustrations: Tables and illustrations (both numbered in Arabic numerals) should be prepared on separate pages. Tables require a heading and figures a legend, also prepared on a separate page. For technical reasons, figures with a screen background should not be submitted. When possible, group several illustrations on one block for reproduction ( $\max$. size $180 \times 223 \mathrm{~mm}$ ) or provide crop marks. Electronically submitted $\mathrm{b} / \mathrm{w}$ half-tone and color illustrations must have a final resolution of 300 dpi after scaling, line drawings one of $800-1,200 \mathrm{dpi}$. Figure files must not be embedded in a document file but submitted separately (for detailed instructions, see http://www. karger.com/goi).

Color illustrations

Online edition: Color illustrations are reproduced free of charge. In the print version, the illustrations are reproduced in black and white. Please avoid referring to the colors in the text and figure legends.

Print edition: Up to 6 color illustrations per page can be integrated within the text at CHF 800.- per page.

References: In the text identify references by Arabic numerals [in square brackets]. Material submitted for publication but not yet accepted should be noted as 'unpublished data' and not be included in the reference list. The list of references should include only those publications which are cited in the text. Do not alphabetize; number references in the order in which they are first mentioned in the text. The surnames of the authors followed by initials should be given. There should be no punctuation other than a comma to separate the authors. Preferably, please cite all authors. Abbreviate journal names according to the Index Medicus system. Also see International Committee of Medical Journal Editors: Uniform requirements for manuscripts submitted to biomedical journals (www.icmje.org).

Examples

(a) Papers published in periodicals: Sun J, Koto $\mathrm{H}$, Chung KF: Interaction of ozone and allergen challenges on bronchial responsiveness and inflammation in sensitised guinea pigs. Int Arch Allergy Immunol 1997;112:191-195.

(b) Papers published only with DOI numbers:

Theoharides TC, Boucher W, Spear K: Serum interleukin-6 reflects disease severity and osteoporosis in mastocytosis patients. Int Arch Allergy Immunol DOI: $10.1159 / 000063858$

(c) Monographs: Matthews DE, Farewell VT: Using and Understanding Medical Statistics, ed 3, revised. Basel, Karger, 1996.

(d) Edited books: Parren PWHI, Burton DR: Antibodies against HIV-1 from phage display libraries: Mapping of an immune response and progress towards antiviral immunotherapy; in Capra JD (ed): Antibody Engineering. Chem Immunol. Basel, Karger, 1997, vol 65, pp 18-56.

Reference Management Software: Use of EndNote is recommended for easy management and formatting of citations and reference lists.

\section{Categories of Manuscripts}

Original Articles

They should not exceed 4 printed pages (3,000 words or approx. 9 manuscript pages double-spaced), including tables, illustrations and references.

Reviews

Reviews are welcomed; however, the Editor-in-Chief is happy to discuss potential articles with authors who would like to contribute.

\section{Systematic Reviews}

For systematic reviews of studies examining interventions or diagnostic procedures, we refer to the $\mathrm{Co}$ chrane Collaboration (www.Cochrane.org). As they represent 'the state of the art', they provide an exceptionally useful handbook. Systematic reviews need not only be the results of intervention studies but can be made on all kinds of research questions, even those that can only be answered by non-experimental studies or interpretive research. For example, a systematic review can be made on qualitative studies - for the 'Qualitative method group' of reviews, the Cochrane Collaboration is a useful information source. All systematic reviews must take and document the following steps:

1. Specification of a research question. A systematic review addresses a specific question rather than provides a general summary of the literature on a topic of interest as is in a traditional review, e.g. for an intervention study it must specify population, intervention, control group and outcome.

2. Development of a review protocol. Systematic reviews use a specified method that is planned beforehand and documented in a review protocol to avoid the risk of bias. A review protocol describes the complete review process, including research
KARGER

Fax +41 613061234

E-Mail karger@karger.ch

www.karger.com 
questions, literature search strategy, selection criteria, criteria for evaluation of methodological quality and how data will be summarized.

3. Systematic literature search. For a systematic review, the search strategy for the literature should be reported and should be repeatable. It includes several steps: a literature search to identify optimal key search terms, databases and search strategy; the search itself; the search of the reference lists of all included studies for the identification of additional studies (snowball method).

4. Selection of relevant studies. This must be done on the basis of selection criteria (e.g. populations, outcome measures, ... to include/exclude) described in the protocol. It protects the review from investigator bias, e.g. (un)consciously including studies on the basis of their results.

5. Evaluation of the methodological quality of each study. The quality of a systematic review depends on the quality of the studies included. Therefore, all studies must be assessed for methodological rigor because the results are only valid if the methods are. Critical appraisal of all studies must be reported and, depending on the research design, categories must be specified.

6. Data collection from individual studies. The data that must be collected depends on the research question and must overcome the different methods of reporting and presenting data in the individual studies. It is useful to use a tool such as a literature table.

7. Synthesis of the findings. The aim of this phase is to summarize the findings from individual studies in an objective manner. The technique depends on the type of studies included. Under certain circumstances (same question, same population, same administration of the intervention, same outcome), the results of experimental studies can be pooled by meta-analysis. The results of nonexperimental studies relating to a phenomenon of interest can be summarized in a meta-synthesis which is an interpretive rather than a cumulative exercise used in meta-analysis.

Narrative Reviews

If the authors are of the opinion that a systematic review is not possible for a specific topic/clinical question, they may opt for a narrative review. For narrative reviews, authors are also requested to have an appropriately formulated research question, to specify their literature search, to carefully consider and discuss the methodological quality of all studies included, and to give an objective summary of the results and conclusion. Narrative reviews need to contain at least the following items:

- Key words used in the electronic search

- Identification of electronic database(s) searched by authors

- Exact definition of time period of publications searched by authors (start and end dates)

- Number of relevant titles identified by authors

- Number of published abstracts read by authors

- Number of full papers read by authors

- Number of cases published in international peerreviewed literature (if review on case reports)

- Reason for inclusion or exclusion by authors of specific publications

- Summary table of included publications allowing comparison regarding significant findings

- Summary statement taking into account all available evidence
References

Joanna Briggs Institute: An Introduction to Systematic Reviews. Changing practice, 2001, vol 2, issue 1. Retrieved October 29, 2008, from http:// www.joannabriggs.edu.au.

Evans D, Pearson A: Systematic reviews: gatekeepers of nursing knowledge. J Clin Nurs 2001;10:593599.

Polit DF Beck CT: Nursing Research: Principles and Methods, ed 7. Philadelphia, Lippincott Williams \& Wilkins, 2004.

\section{Novel Insights from Clinical Practice}

This category replaces the previous Case Report section.

We invite contributions to this section that provide novel insight into a clinical problem.

We recognise the value of case reports and thus submissions can be based around a case or a number of similar cases. The most important aspect of the presentation is that it should provide a new perspective on a recognised clinical scenario or may represent an entirely new clinical condition. The novel aspects of the case(s) may be in the phenotype, the presentation, the investigation and/or the management.

We propose that a highlighted box containing one or two bullet points on 'Established Facts' (what is already known) and 'Novel Insights' (what new information has been gained) be placed on the first page of the report. This will reinforce the novelty of the clinical observation. The manuscript should be presented with an unstructured abstract (max. 200 words), brief introduction, case or case series description and results, followed by a discussion. Maximum 3 figures.

Summaries of PhD Theses: A Summary of a PhD Thesis is supposed to give a review of the different papers that are part of a particular $\mathrm{PhD}$ thesis which has been successfully defended within the last 3 years. The review should have at least 6,000 words and a maximum of 10,000 words of text with a maximum of 200 references, 5 tables and 5 figures. Considerable emphasis should be given to an overall systematic discussion of the $\mathrm{PhD}$ findings, and their implication for clinical practice and/or research.

\section{Letters to the Editor}

This section is set aside for critical comments directed to a specific article that has been published in the journal. Letters should be brief (not exceeding 500 words), double spaced and limited to a maximum of 5 citations. The letters and replies should be prepared according to journal format. Illustrative material is only permitted with permission of the Editor-inChief. With your correspondence, please include your complete mailing address, telephone and fax numbers, and email addresses, if available. The Editor-in-Chief reserves the right to refuse letters, shorten letters, delete objectional comments, and make other changes to comply with the style of the journal. Send all Letters to the Editor to the above address.

\section{Digital Object Identifier (DOI)}

S. Karger Publishers supports DOIs as unique identifiers for articles. A DOI number will be printed on the title page of each article. DOIs can be useful in the future for identifying and citing articles published online without volume or issue information. More information can be found at www.doi.org.

\section{Supplementary Material}

Supplementary material is restricted to additional data that are not necessary for the scientific integrity and conclusions of the paper. Please note that all supple- mentary files will undergo editorial review and should be submitted together with the original manuscript. The Editors reserve the right to limit the scope and length of the supplementary material. Supplementary material must meet production quality standards for Web publication without the need for any modification or editing. In general, supplementary files should not exceed $10 \mathrm{MB}$ in size. All figures and tables should have titles and legends and all files should be supplied separately and named clearly. Acceptable files and formats are: Word or PDF files, Excel spreadsheets (only if the data cannot be converted properly to a PDF file), and video files (.mov, .avi, .mpeg).

\section{Author's Choice ${ }^{\mathrm{TM}}$}

Karger's Author's Choice ${ }^{\mathrm{TM}}$ service broadens the reach of your article and gives all users worldwide free and full access for reading, downloading and printing at www.karger.com. The option is available for a onetime fee of CHF 3000.-, which is a permissible cost in grant allocation. More information can be found at www.karger.com/authors_choice.

\section{NIH-Funded Research}

The U.S. National Institutes of Health (NIH) mandates under the NIH Public Access Policy that final, peer-reviewed manuscripts appear in its digital database within 12 months of the official publication date. As a service to authors, Karger submits the final version of your article on your behalf to PubMed Central. For those selecting our premium Author's Choice ${ }^{\mathrm{TM}}$ service, we will send your article immediately upon publishing, accelerating the accessibility of your work without the usual embargo. More details on NIH's Public Access Policy is available at http:// publicaccess.nih.gov/FAQ.htm\#a1

\section{Self-Archiving}

Karger permits authors to archive their pre-prints (i.e. pre-refereeing) or post-prints (i.e. final draft post-refereeing) on their personal or institution's servers, provided the following conditions are met: Articles may not be used for commercial purposes, must be linked to the publisher's version, and must acknowledge the publisher's copyright. Authors selecting Karger's Author's Choice ${ }^{\mathrm{TM}}$ feature, however, are also permitted to archive the final, published version of their article, which includes copyediting and design improvements as well as citation links.

\section{Page Charges}

Each additional complete or partial page above 4 printed pages is charged to the author at CHF 325.--

\section{E-pub First}

All articles are published electronically ahead of print with a DOI number and are supplemented later with the definite reference of the printed version. The articles become available immediately after the authors approval to publication, with the added advantage of being citable much earlier than in print. Authors can influence the time of appearance by promptly returning the proofs.

\section{Proofs}

PDF proofs are sent to the corresponding author and should be returned with the least possible delay.

\section{Reprints}

Order form and price list is sent with the PDF proofs. Orders submitted after the issue is printed are subject to considerably higher prices.

\section{KARGER}

Fax +41 613061234

E-Mail karger@karger.ch

www.karger.com 
Gynecologic and

Obstetric Investigation

ISSN Print Edition: $0378-7346$

ISSN Online Edition: 1423-002X

Journal Homepage: www.karger.com/goi

Publication Data: 'Gynecologic and Obstetric Investigation' is published 8 times a year. Volumes 73 and 74 , each with 4 issues, appear in 2012.

Copyright: (c) 2012 S. Karger AG, Basel (Switzerland). All rights reserved. No part of this publication may be translated into other languages, reproduced or utilized in any form or by any means, electronic or mechanical, including photocopying, recording, microcopying, or by any information storage and retrieval system, without permission in writing from the publisher or, in the case of photocopying, direct payment of a specified fee to the Copyright Clearance Center.

Disclaimer: The statements, opinions and data contained in this publication are solely those of the individual authors and contributors and not of the publisher and the editor(s). The appearance of advertisements in the journal is not a warranty, endorsement, or approval of the products or services advertised or of their effectiveness, quality or safety. The publisher and the editor(s) disclaim responsibility for any injury to persons or property resulting from any ideas, methods, instructions or products referred to in the content or advertisements.
Subscription Rates: Subscriptions run for a full calendar year. Prices are given per year. Personal subscription:

Print or Onlin

CHF 1546.-

EUR 1236.-

Print+Online combined

USD 1500.00

CHF 1642.-

EUR 1312.-

USD 1594.00

postage and handling (added to print and print+online)

CHF 54.40 Europe, CHF 80.00 Overseas

EUR 41.60

USD 75.20

Institutional subscription:

Print or Online

Print+Online combined

CHF 3090.-

CHF 3400.-

EUR 2472.-

EUR 2720.-

USD 3000.00

USD 3300.00

postage and handling (added to print and print+online)

CHF 68.- Europe, CHF 100.- Overseas

EUR 52.-

USD 94.00

Airmail surcharge: CHF 68.- / USD 64.00

Discount subscription prices:

Society for Gynecologic Investigation
Back Volumes and Single Issues: Information on availability and prices of single print issues and print or electronic back volumes can be obtained from Customer Service at service@karger.ch.

Bibliographic Indices: This journal is regularly listed in bibliographic services, including Current Contents and PubMed/MEDLINE.

Photocopying: This journal has been registered with the Copyright Clearance Center (CCC), as indicated by the code appearing on the first page of each article. For readers in the US, this code signals consent for copying of articles for personal or internal use, or for the personal or internal use of specific clients, provided that the stated fee is paid per copy directly to

Copyright Clearance Center Inc.

222 Rosewood Drive

Danvers, MA 01923 (USA)

A copy of the first page of the article must accompany payment. Consent does not extend to copying for general distribution, for promotion, for creating new works, or for resale. In these cases, specific written permission must be obtained from the copyright owner

S. Karger AG, P.O. Box

CH-4009 Basel (Switzerland).
Subscription Orders:

Orders can be placed at agencies, bookstores, directly with the Publisher

\section{S. Karger AG}

Medical and Scientific Publishers

P.O. Box

CH-4009 Basel

Switzerland

(for courier services only:

Allschwilerstrasse 10

CH-4055 Basel)

t: +41613061111

f: +41613061234

e: karger@karger.ch

w: www.karger.com or further Karger offices

or representatives:

Germany

S. Karger GmbH

Postfach

79095 Freiburg

Deutschland

(Hausadresse: Wilhelmstrasse 20A,

79098 Freiburg)

$\mathrm{t}: \quad+49761452070$

f: +497614520714

e: information@karger.de

w: www.karger.de

Japan

Karger Japan, Inc.

Shiba Daimon Asahi Bldg. 2F

1-2-23 Shiba Daimon

Minato-ku

Tokyo 105-0012

Japan

t: +81364356242

f: +81364356244

e: publisher@karger.jp

w: www.karger.jp

Change of Address:

Both old and new address should be sent

to the subscription source.

USA

S. Karger Publishers, Inc.

26 West Avon Road

P.O. Box 529

Unionville, CT 06085

USA

Toll free: +18008285479

t: +18606757834

f: +18606757302

e: karger@snet.net

France

Librairie Médi-Sciences Sar

36, bd de Latour-Maubourg

75007 Paris

France

t: $+33(0) 145514258$

f: $+33(0) 145560780$

f: +33(0) 145560780

e: librairie@medi-sciences.

Gulf Council Countries, Iran,

Middle East, North Africa, Turkey

Trans Middle East International

Distribution Co. Ltd.

KaSha

134 Queen Rania Al Abdullah Street

Jordan Trade Center Bldg. 3rd Floor

P.O. Box 2376

Amman 11953

Jordan

$\mathrm{t}$ : +96265153467

f: +96265153472

e: info@kasha.cc

w: www.KaShaonline.com
South East Asia, China and Taiwan Karger Regional Office (Malaysia)

CEO Suite Kuala Lumpur

Quill 7, 27th Floor

Jalan Stesen Sentral 5

KL Sentral

Kuala Lumpur 50470

Malaysia

t: +60327766803

f: +60327766999

e: service@karger.cn; r.chew@karger.cn

\section{Karger China}

10th Floor, Twin Towers (East)

B12 Jianguomenwai Avenue

Beijing 100022

China

t: +861051235033

f: +861051235122

e: service@karger.cn; r.chew@karger.cn

w: www.karger.cn

India, Bangladesh, Sri Lanka

Medscience India

Plot No. 17, Yusuf Sarai Market

B.L. Glass Building, 2nd Floor

Sri Aurobindo Marg

New Delhi 110016

India

t: +911146029633

f: +911146029634

c: +919891052128

e: medsci.india@gmail.com

\section{KARGER}

Fax +41 613061234

E-Mail karger@karger.ch

www.karger.com
(C) 2012 S. Karger AG, Basel

The Journal Home Page is available at:

www.karger.com/goi 


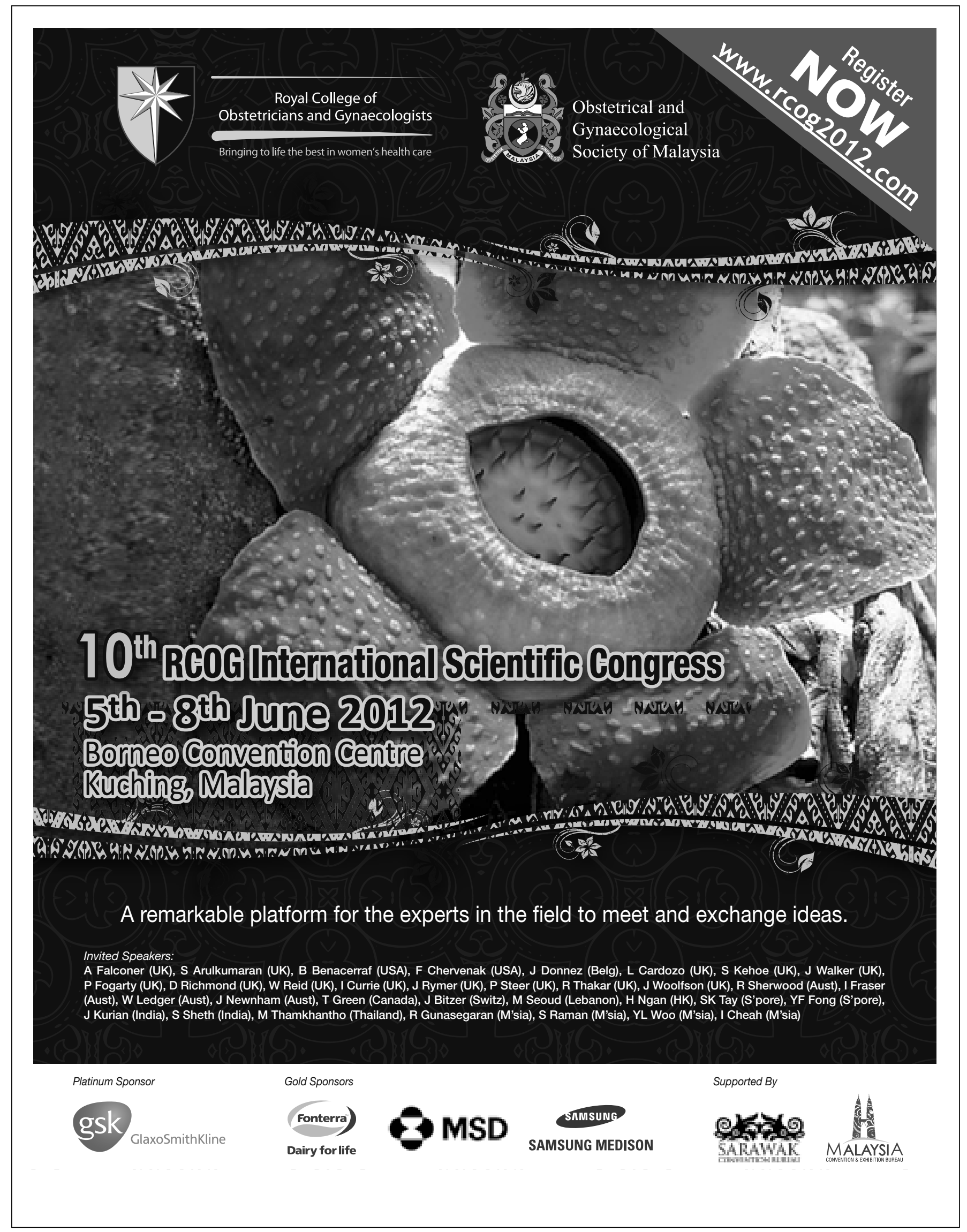




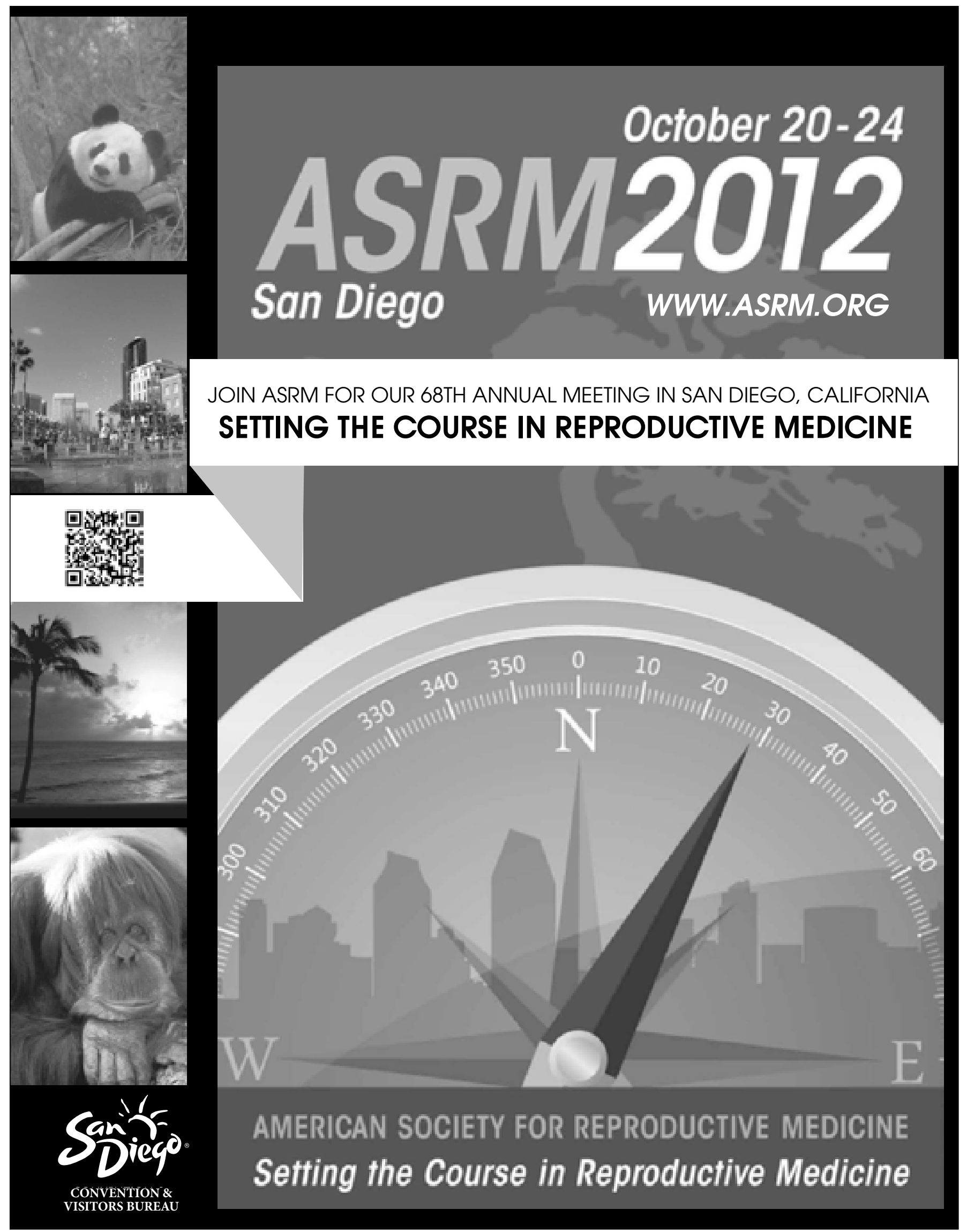




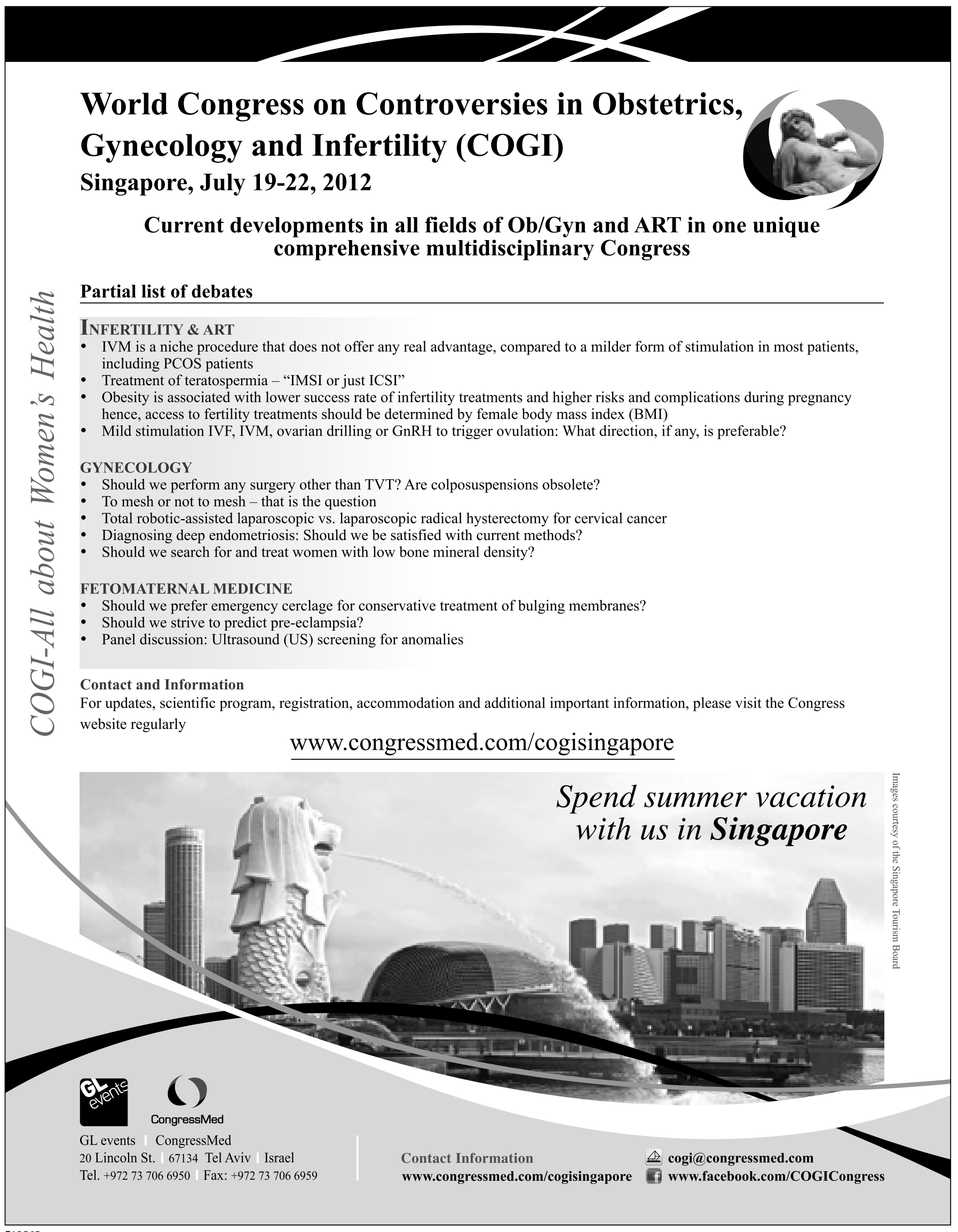




\section{CONFERENCE OF

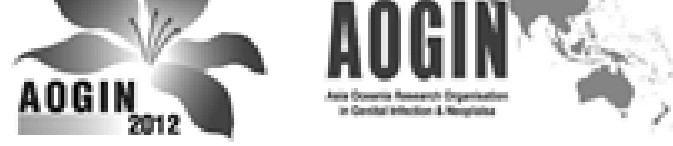 ASIA OCEANIA RESEARCH ORGANISATION ON GENITAL INFECTIONS AND NEOPLASIA}

\section{Combat against Cervical Cancer - Challenges in Asia Oceania}

13-15 July 2012

Cheung Kung Hai Conference Centre, The University of Hong Kong

Hong Kong

Host Organiser:

Department of Obstetrics and Gynaecology

The University of Hong Kong

Highlight of the Scientific Programme

Prof. Dr. Harald zur Hausen

Heidelberg, Germany

Winner of the Nobel Prize in Medicine in 2008

Persistence of putative tumor viruses in human cancer cells

For further details, please visit our conference website:

http://www.aogin2012hk.org

Deadline for Late Registration 15 May 2012

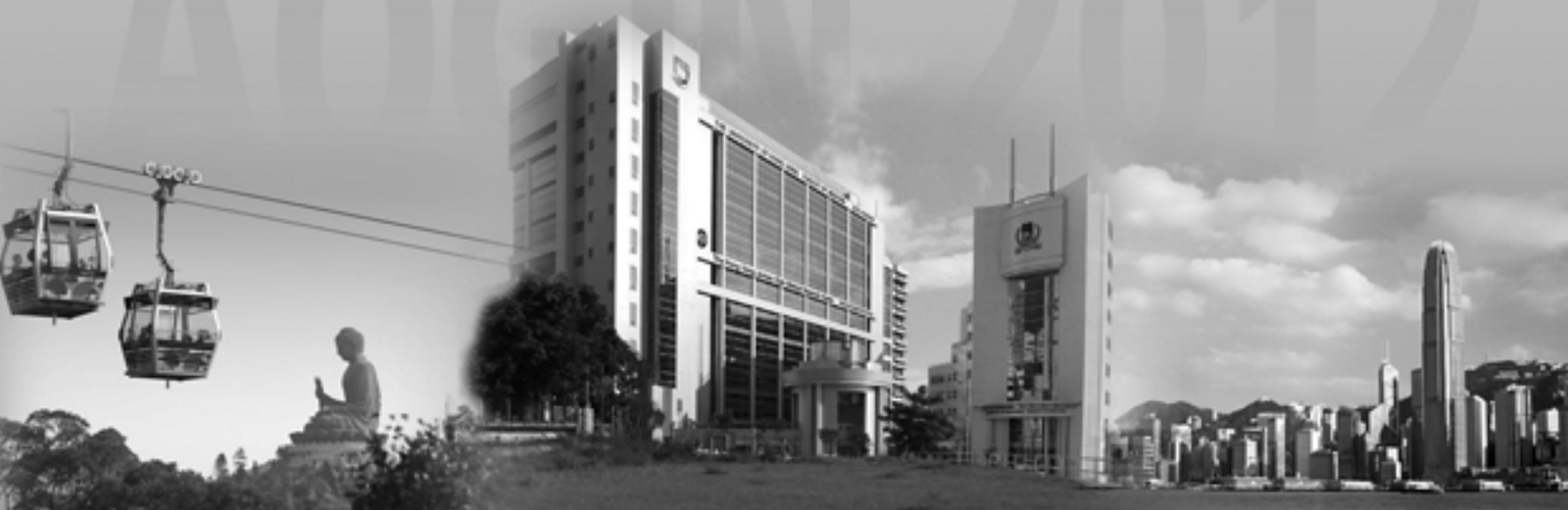

Conference Secretariat

PC TOURS AND TRAVEL Tel: (852) 2734 3312, 27343315 Fax: (852) 2367 3375, 27239044 Email: aogin2012@pctourshk.com 


\section{Contents}

See the journal website for contents

KARGER Basel $\bullet$ Freiburg $\cdot$ Paris $\bullet$ London $\bullet$ New York $\cdot$ New Delhi $•$ Bangkok Beijing $\cdot$ Tokyo $\cdot$ Kuala Lumpur $\cdot$ Singapore $\bullet$ Sydney 


\section{7th \\ ANNUAL MEETING \\ SEPTEMBER 04-08,2012}

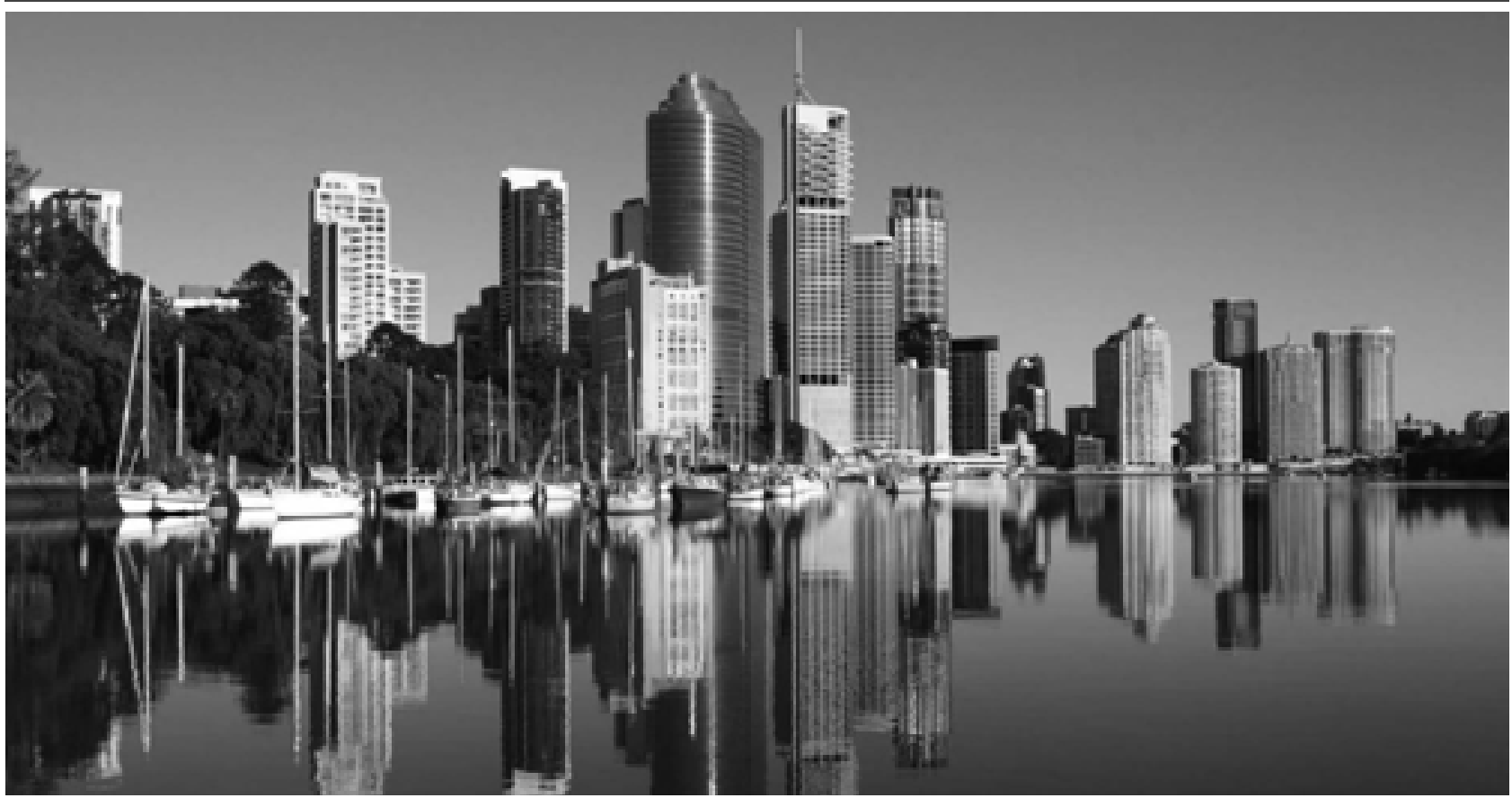

\section{BRISBANE AUSTRALIA}

BRISBANE CONVENTION \& EXHIBITION CENTER Registration Opens April 2, 2012

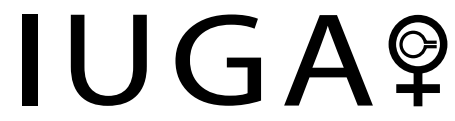

INTERNATIONAL UROGYNECOLOGICAL ASSOCIATION

For more information:

www.iuga2012.com
Ulf Ulmsten Memorial Lecture

"Teaching and learning in urogynaecology"

Anthony R. Smith, UK

\section{State of the Art Lecture}

"From research to commercial reality: trials and tribulations with the cervical vaccine" Ian Frazer, Australia

PRO \& CON/Interactive Session

"The FDA got it all wrong on transvaginal meshes"

Affirmative: Michel Cosson, France and Dennis Miller, USA

Negative: Matthew D. Barber, USA and Kaven Baessler, Germany

\section{Roundtable}

"Can the Pelvic floor withstand vaginal delivery Mechanics of childbirth and the pelvic floor" John O. DeLancey, USA

"Perils of vaginal delivery in 2012"

Don Wilson, New Zeland

PRO \& CON/Interactive Session

"Pelvic floor exercises are overrated"

Affirmative: James Malone-Lee, UK and

Soren Brostrom, Denmark

Negative: Kari Bo, Norway and

Helena Frawley, Australia

\section{HIGHLIGHTS}

50 podium presentations

I50 oral posters

300 posters

Over 20 small group workshops John Delancey: Cadaver course (off site)

Mickey Karram: live surgery course Welcome Reception:

"Brisbane Style" - on the Beach

Closing Night Celebration

* Speakers subject to change
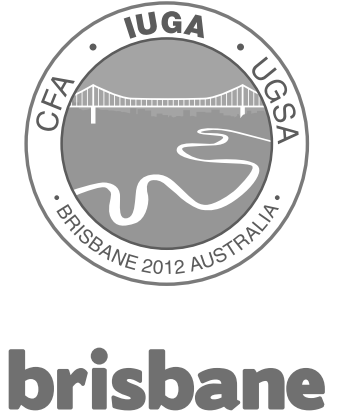

australia's new world city 


\section{ASRM eLeari"}

Online Learning for Reproductive Healthcare Professionals

\section{Online education for physicians and} allied healthcare professionals

\section{CME | Nursing CE | PEER}

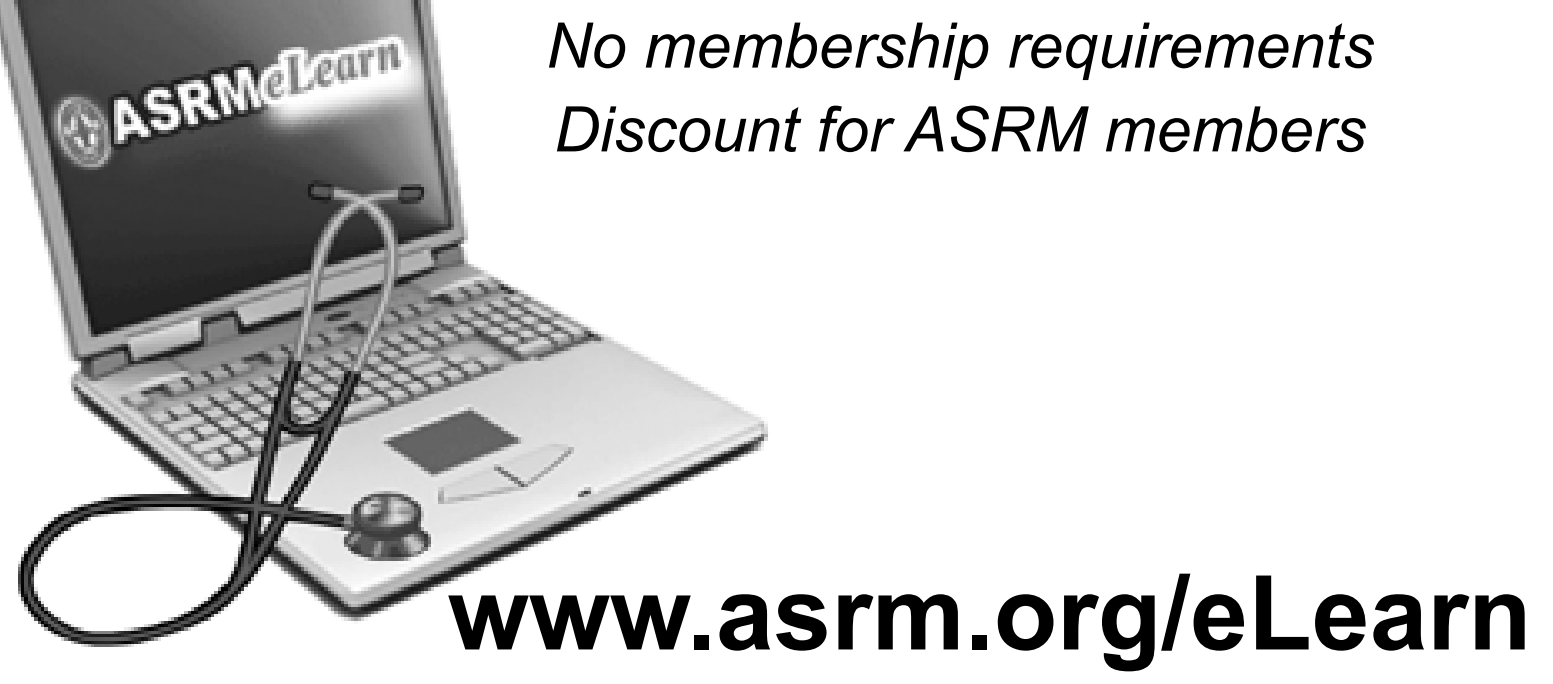

Visit www.asrm.org/eLearn for an online eLearn demonstration and more information on our catalogue of offerings and how to get started. 


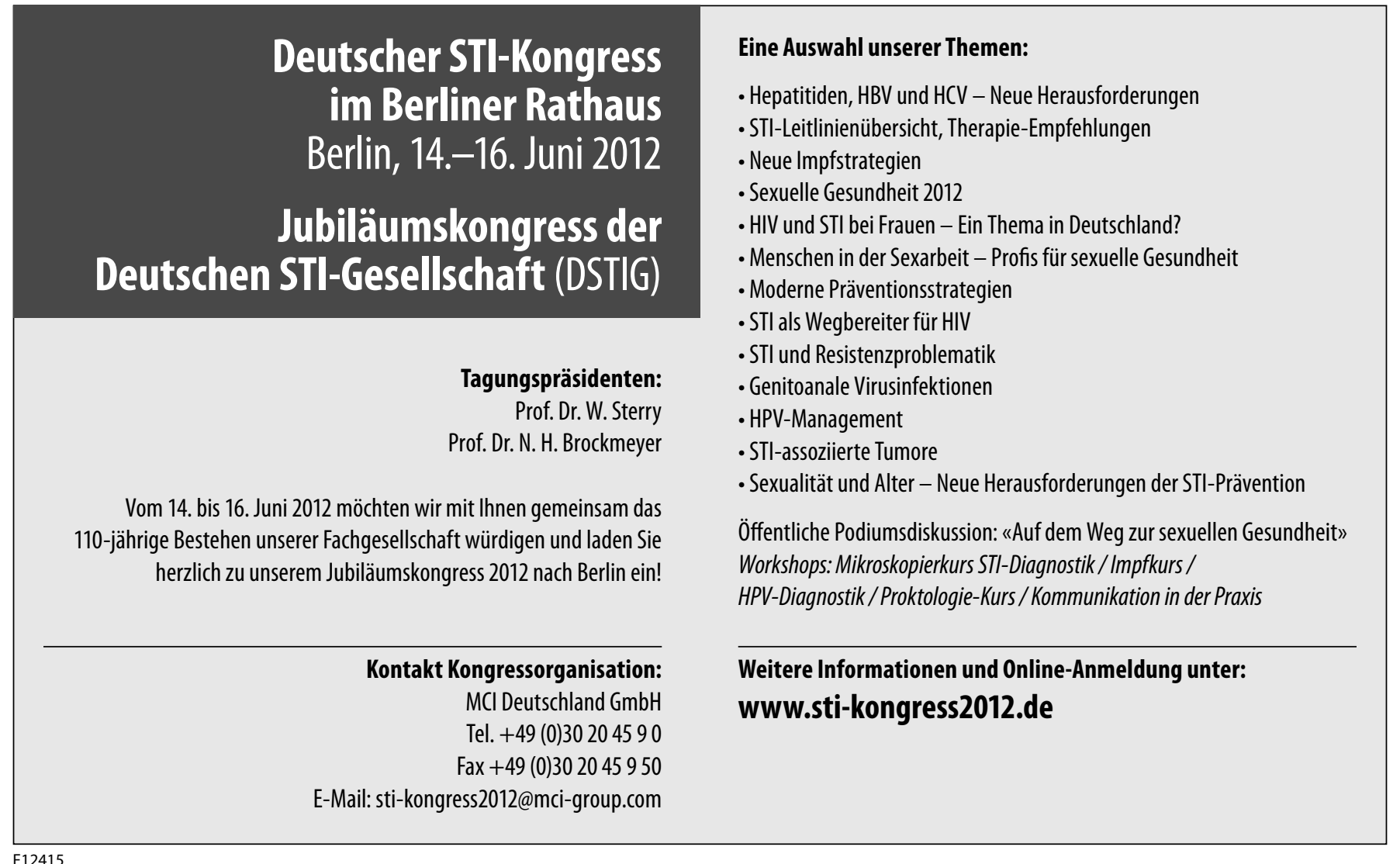

\section{'A collection of extraordinary essays'}

\section{GOTTFRIED SCHATZ}

\section{A MATTER OF WONDER}

What Biology Reveals about Us, Our World, and Our Dreams

Where do we come from? Is our destiny determined by the genes we inherit? In this book Gottfried Schatz, the world-renowned biochemist and co-discoverer of mitochondrial DNA, gives lucid - albeit often surprising - answers to universal questions and takes the reader on a fascinating journey of discovery across the boundaries of scientific disciplines. With passion and a keen sense of wonder he draws on philosophy, cultural history and art to formulate his reflections on the mysteries of life. His essays will appeal not only to scientists but to all inquisitive minds, regardless of educational and professional background.

\section{KARGER}

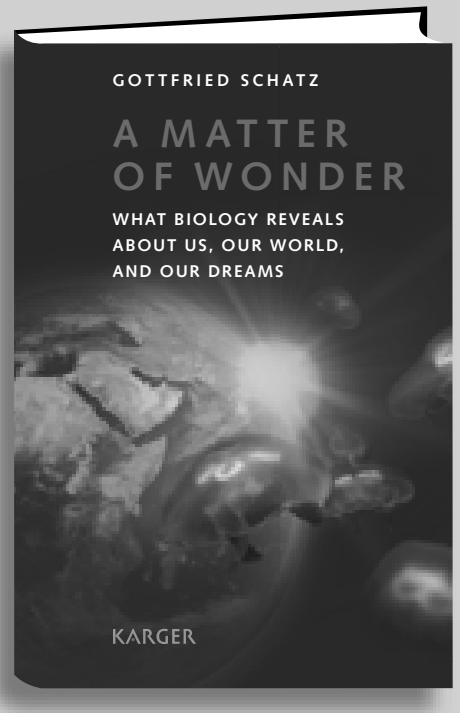

G. Schatz (Basel)

\section{A Matter of Wonder}

What Biology Reveals about Us,

Our World, and Our Dreams

Translated by A. Shields

XII +190 p., 2 color fig., hard cover, 2011

CHF 29.-/EUR 21.50/USD 29.00

ISBN 978-3-8055-9744-9

More information and sample essays at www.karger.com/schatz 


\section{Congress Presidents: Xavier Bosch (Spain), Silvia Franceschi (France), Stina Syrjänen (Finland) Chairman of the Program Committee: Joseph Monsonego (France)}

The conference aims at developing a full overview of current scientific advances in the field of cervical cancer and HPV related diseases of other sites (anus, skin, head \& neck), raising the public health profile and increasing the need for responsive health services in this area. The event focuses on translating scientifc and evidence based research into clinical practice and offers a high quality and innovative scientific program drawn up by outstanding international leaders from the academic sector as well as professional and patient organizations.

\section{Key objectives:}

Assessing the impact of HPV and associated cancers on public health - Identifying strategies to prevent and treat HPV associated diseases Exchanging information on early detection, new diagnostic and therapeutic procedures and prevention strategies including screening and HPV vaccination.
Target audience:

- Clinicians from several disciplines

- Gynecologists

- Oto-rhino-laryngologists/head \& neck oncologists

- Dermato-venereologists

- Basic scientists - Epidemiologists - Cytopathologists - Biologists

\section{PROGRAM STRUCTURE}

MAIN TRAINING COURSE (July 8, 2012).

- Full day training course on HPV infection and associated diseases: Fundamentals - Screening and Vaccination - Management - HPV related neoplasia and cancer in the cervix, external genitalia and other sites

MAIN SCIENTIFIC SESSIONS (July 9-10, 2012).

- $\quad \mathrm{HPV}$ associated diseases in non anogenital sites

- HPV based screening strategies

- $\quad H P V$ vaccines: update \& perspectives

- New screening experiences - HPV vaccine implementation

- Hot topics on HPV infection \& diseases

- Controversial issues in the field of HPV - how can models help our understanding?

- $\quad$ HPV DNA \& mRNA testing

- Genotyping

- Molecular markers

OTHER SCIENTIFIC SESSIONS (July 10-11, 2012).

The program includes more than 20 other scientific sessions on a wide range of topics.

These sessions are open for the presentation of original papers.

OTHER TRAINING COURSES AND EDUCATIONAL SESSIONS

- Colposcopy - Gynecological oncology

- Vulvar diseases - Publishing in clinical and public health research
International Forum on HPV and Head \& Neck Cancer Oropharyngeal cancer is one of the fastest rising cancers in many countries. This has been attributed to the rise in HPV- head and neck cancer. This new disease entity appears to have significantly better survival outcomes. However, important questions arise regarding its natural history, diagnosis, patient counselling and the best management regimens. This Forum includes dedicated sessions extending over 3 days on HPV infection in head \& neck cancers as well as a specialized seminar.

\section{International Forum on HPV and Skin / Dermatovenereology}

HPV is definitely involved in the origin and development of genitoanal cancer of both genders. The role of beta papillomaviruses in squamous cell cancer of the skin is subject of numerous scientific investigations. This forum is organized in cooperation with EADV (European Academy of Dermatology and Venereology) and SCOPE (Skin Care in Organ Transplant Patients).

This Forum includes dedicated sessions extending over 3 days on HPV and skin / dermatovenereology as well as a specialized seminar.
For further information, including the program, online registration and abstract submission, please visit the conference website: www.eurogin.com/2012

or contact: admin@eurogin.com
CME (Continuing Medical Education)

EUROGIN 2012 is accredited by the European Accreditation Council for Continuing Medical Education (EACCME) for a maximum of 21 hours of European external CME credits. EACCME credits can be converted to AMA PRA Category 1 Credits $^{\mathrm{T} \mathrm{M}}$. 


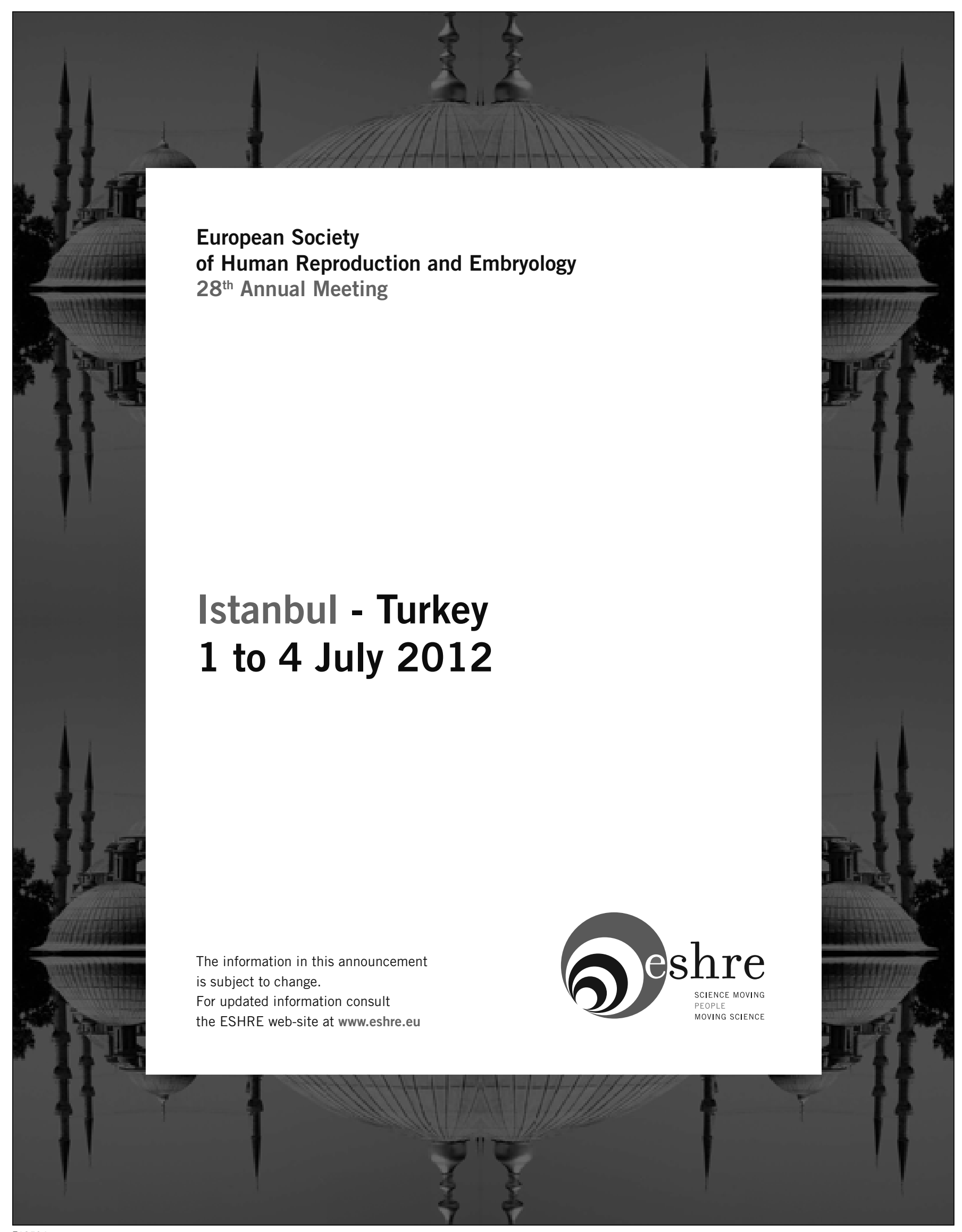




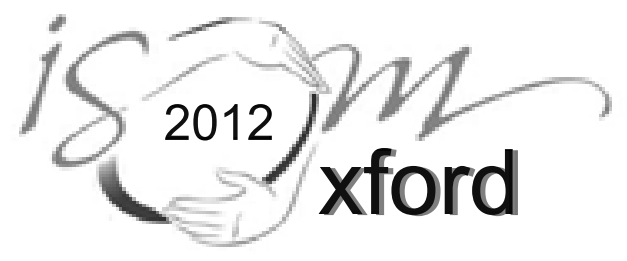

\section{The 6th Biennial Scientific Meeting of ISOM \\ (International Society of Obstetric Medicine)}

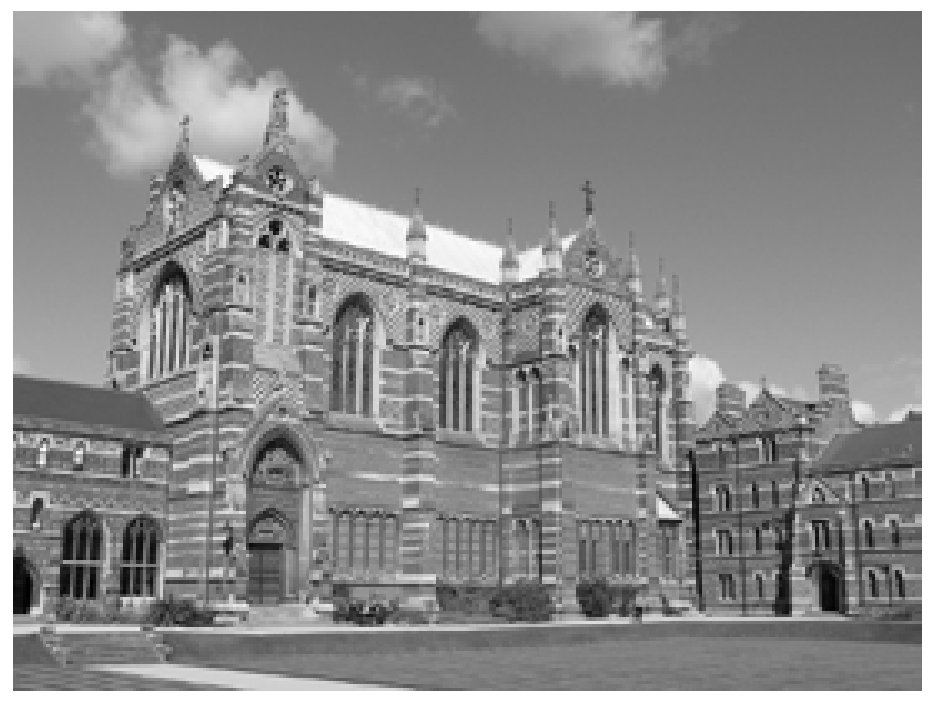

\section{Saturday \& Sunday, 7 \& 8 July 2012 at Keble College, Oxford, UK}

An exciting programme of international speakers has been planned to stimulate lively discussion amongst physicians, obstetricians, anaesthetists, researchers, nurses, midwives and anyone interested in medical problems in pregnancy.

Accommodation is available at Keble College in ensuite rooms at very reasonable rates. Reduced registration fees are available for members of ISOM/MOMS, early birds (by 30 March 2012) and trainees.

Abstracts are invited and there is a prize of US\$500 each for best poster, best oral and a travel grant to the trainee who submits the best written abstract.

wWw.isom2012.org

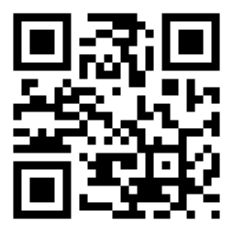




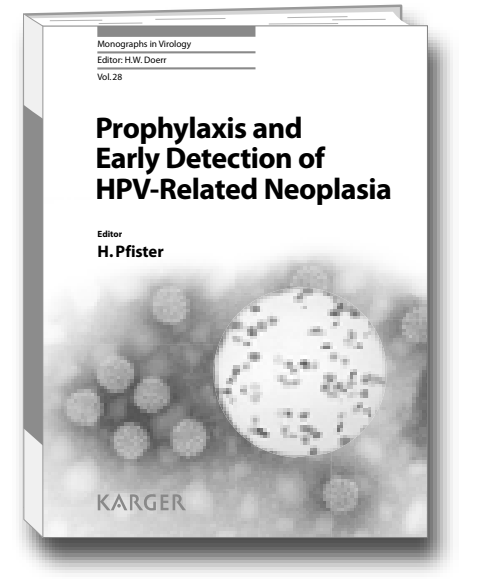

Human papillomaviruses (HPV) are a heterogeneous and still growing virus family. Topical research results on the replication cycle and carcinogenic mechanisms allow a better understanding of current prevention strategies. Written by leading experts, this volume of Monographs in Virology provides up-to-date information on the prevention of papillomavirus-induced cancers by prophylactic antiviral vaccines and early detection of precancerous lesions.

A major section covers the tremendous clinical burden due to HPV infections: genital warts and laryngeal papillomas, the most notorious cervical cancer, but also further anogenital and tonsillar cancer, the incidence of which increased steeply during the last decades. Additionally, a section on prevention addresses the subject cytology - new concepts of biomarker development, detection of HPV DNA and RNA as well as their use in primary screening for early detection of precancerous lesions. Finally the book closes with a topical discussion of the most intriguing primary prevention of HPV infection by vaccination.

As new perspectives for the prevention of HPVrelated neoplasia raised great public interest, this book will be of value to clinicians and practitioners in gynecology, dermatology, urology and ENT, to pathologists, laboratory physicians, medical students, and public health authorities.

\section{Prophylaxis and Early Detection of HPV-Related Neoplasia}

\author{
Editor \\ Herbert Pfister
}

\section{Contents}

Foreword: Pfister, $\boldsymbol{H}$.

Virology and Pathogenesis: Pfister, $\boldsymbol{H}$.

Epidemiology of Mucosotropic Papillomaviruses: Gissmann, $\boldsymbol{L}$.

Clinical Aspects of Low-Risk HPV Infections

- Condylomata Acuminata: Gross, G.

- Recurrent Respiratory Papillomatosis: Wittekindt, C.; Wagner, S.; Klussmann, J.P.

Clinical Aspects of High-Risk HPV Infections - Cervical Cancer and Intraepithelial Neoplasia: Schneider, A.; Köhler, C.; Chiantera, V.; Vercellino, $F$.

- Cancer and Intraepithelial Neoplasia of the Vulva and Vagina: Petry, K.U.

- Penile Cancer and Penile Intraepithelial Neoplasia: Gross, G.F.

- Anal Cancer and Intraepithelial Neoplasia: Wieland, U.; Kreuter, $A$.

- Tonsillar Cancer: Klussmann, J.P.; Wagner, S.; Wittekindt, C.
Diagnosis for Early Detection

- Cytology: Ikenberg, $\boldsymbol{H}$.

- Concepts of Biomarker Development: von Knebel Doeberitz, M.; Vinokurova, S.; Reuschenbach, $M$.

- Detection of Human Papillomavirus DNA and RNA: Ikenberg, $\boldsymbol{H}$.

- Human Papillomavirus Testing in Primary Screening for Cervical Cancer: Petry, K.U.

Primary Prevention by Vaccination: Kaufmann, A.M.; Gissmann, L.

Author Index

Subject Index

\section{KARGER}

www.karger.com/movir

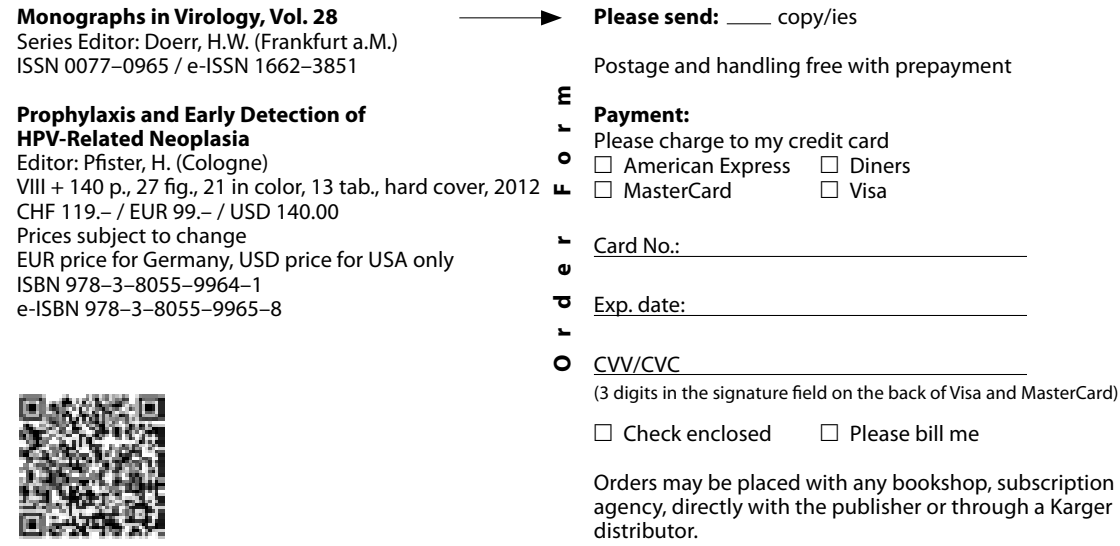

Monographs in Virology, Vol. 28 Series Editor: Doerr, H.W. (Frankfurt a.M.) ISSN 0077-0965 / e-ISSN 1662-3851

Prophylaxis and Early Detection of HPV-Related Neoplasia Editor: Pfister, H. (Cologne) VIII + 140 p., 27 fig., 21 in color, 13 tab., hard cover, 2012 CHF 119.- / EUR 99.- / USD 140.00

Prices subject to change

EUR price for Germany, USD price for USA only

ISBN 978-3-8055-9964-1

e-ISBN 978-3-8055-9965-8

Please send: ___ copy/ies

Postage and handling free with prepayment

$\boldsymbol{\varepsilon}$ Payment:

Please charge to my credit card

- $\square$ American Express $\square$ Diners

+ $\square$ MasterCard $\square$ Visa

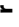

-

$\nabla$

- CVV/CVC

( 3 digits in the signature field on the back of Visa and MasterCard)

$\square$ Check enclosed $\square$ Please bill me

Orders may be placed with any bookshop, subscription agency, directly with the publisher or through a Karger distributor.
Fax: +41613061234

S. Karger AG, P.O. Box, CH-4009 Basel (Switzerland)

E-Mail orders@karger.ch,www.karger.com

Name/Address: 

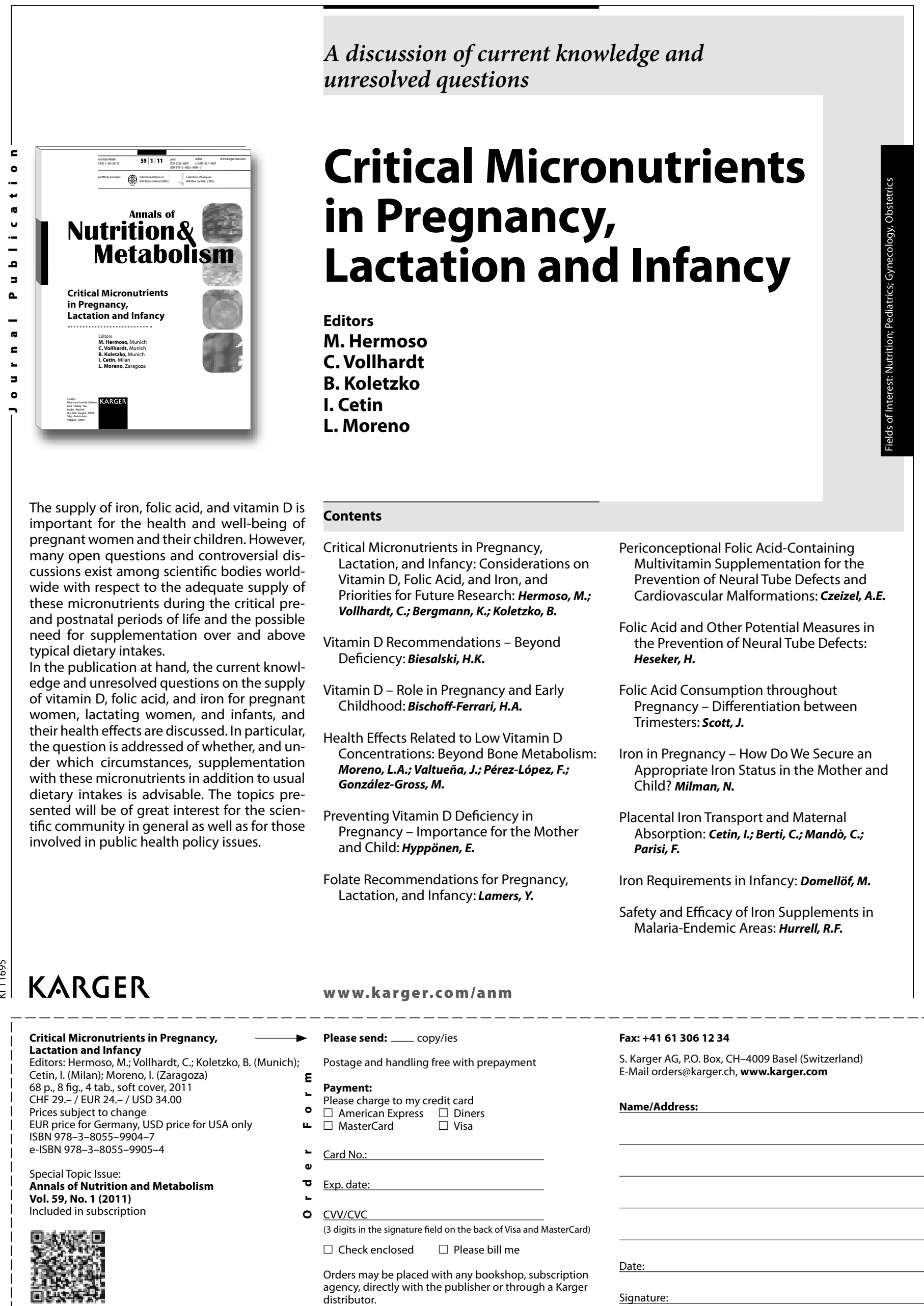

Critical Micronutrients in Pregnancy, $\longrightarrow$ Please send: __ copy/ies

Postage and handling free with prepayment

E Payment:

Please charge to my credit card

- $\square$ American Express $\square$ Diners

ᄂ $\square$ MasterCard $\square$ Visa

- Card No

๑

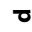

- CVV/CVC

(3 digits in the signature field on the back of Visa and MasterCard)

$\square$ Check enclosed $\square$ Please bill me

Orders may be placed with any bookshop, subscription agency, directly with the publisher or through a Karge distributor.

Fax: +41613061234

S. Karger AG, P.O. Box, CH-4009 Basel (Switzerland)

E-Mail orders@karger.ch,www.karger.com

Name/Address: 


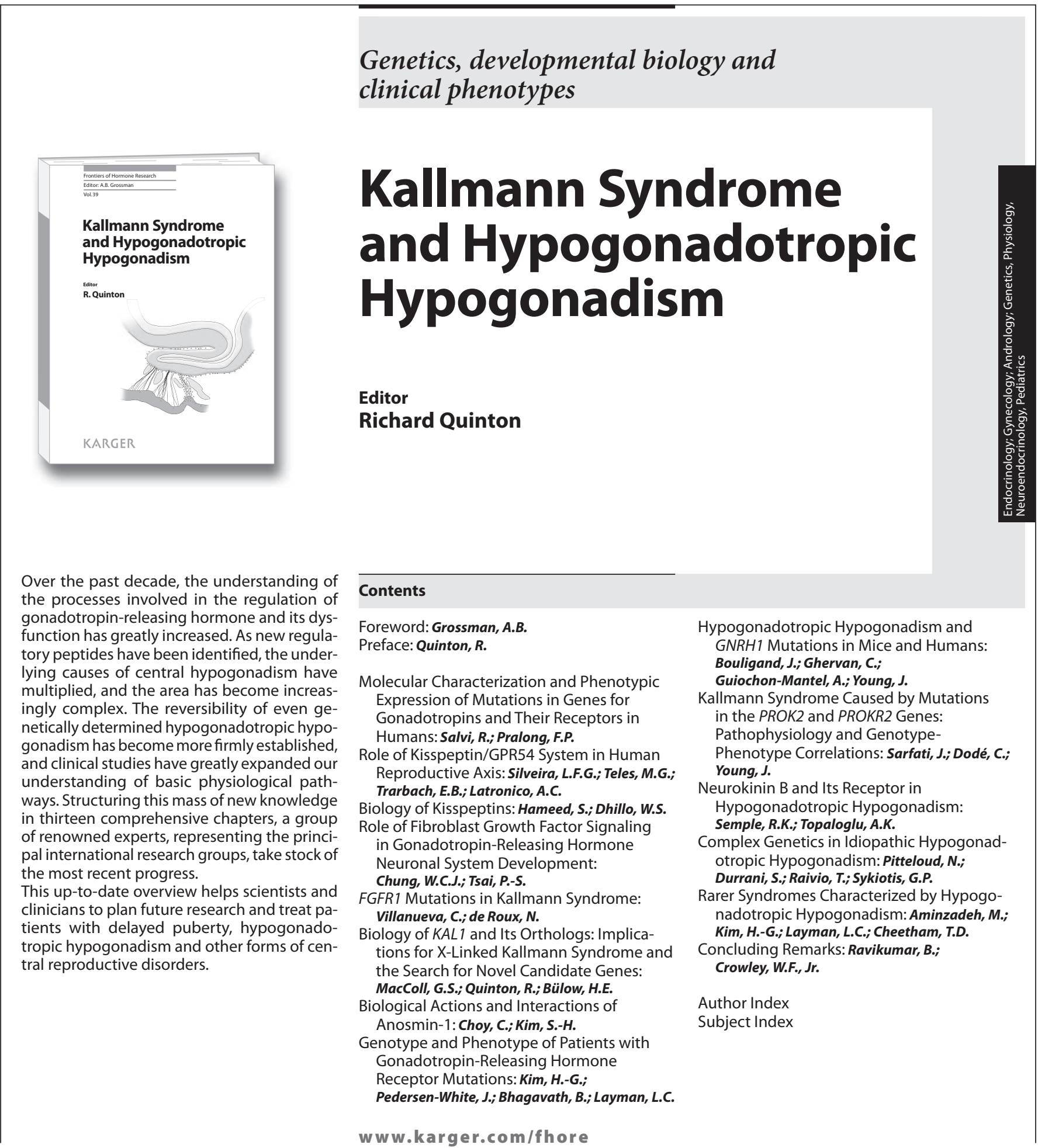

Frontiers of Hormone Research, Vol. 39 Series Editor: Grossman, A.B. (London) ISSN 0301-3073 / e-ISSN 1662-3762

\section{Kallmann Syndrome and Hypogonadotropic} Hypogonadism

Editor: Quinton, R. (Newcastle-upon-Tyne) $X+174$ p., 20 fig., 5 in color, 12 tab., hard cover, 2010 CHF 178.- / EUR 148.- / USD 209.00

Prices subject to change

EUR price for Germany, USD for USA only

ISBN 978-3-8055-8617-7

e-ISBN 978-3-8055-8618-4

KARGER

\section{Please send: copy/ies}

Postage and handling free with prepayment

$\varepsilon$

Payment:

Please charge to my credit card

- $\square$ American Express $\square$ Diners

ᄂ $\square$ MasterCard $\square$ Visa

Card No.

Exp. date:

CVV/CVC

(3 digits in the signature field on the back of Visa and MasterCard)

$\square$ Check enclosed $\quad \square$ Please bill me

Orders may be placed with any bookshop, subscription agency, directly with the publisher or through a Karger distributor.
Fax: +41613061234

S. Karger AG, P.O. Box, CH-4009 Basel (Switzerland)

E-Mail orders@karger.ch,www.karger.com

Name/Address: 


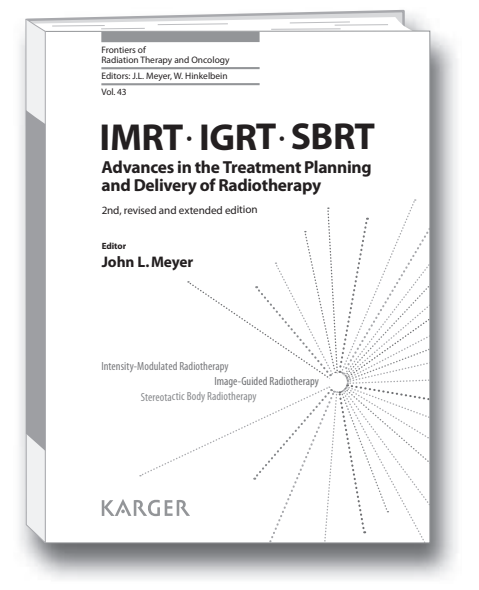

Contents

Preface: Meyer, J.L.

Introduction

General Concepts and Methods

Economic Perspectives

IMRT and IGRT: Intensity-Modulated and Image-Guided Radiotherapy

IMRT: Advances in Treatment Design and Delivery Clinical Implementation of Intensity-Modulated

Arc Therapy: Shepard, D.M.; Cao, D

IGRT: Advances in Targeting Therapy

4D Imaging and 4D Radiation Therapy: A New Era of Therapy Design and Delivery: Low, $\boldsymbol{D}$.

Locating and Targeting Moving Tumors with

Radiation Beams: Keall, $\boldsymbol{P}$.

Integrating IMRT and IGRT into Treatment Delivery Technologies of Image Guidance and the Development of Advanced Linear Accelerator Systems for Radiotherapy: Wu, v.W.C. et al.

Helical Tomotherapy: Image-Guided and Adaptive Radiotherapy: Kupelian, $\boldsymbol{P}_{\text {.; }}$ Langen, $\boldsymbol{K}$.

The CyberKnife in Clinical Use: Current Roles,

Future Expectations: Dieterich, S.; Gibbs, I.C.

www.karger.com/frato

\section{KARGER}

\title{
IMRT, IGRT, SBRT - Advances in the Treatment Planning and Delivery of Radiotherapy
}

\author{
2nd, revised and extended edition
}

Editor

John L. Meyer

IMRT and IGRT Clinical Treatment Programs

Image Guidance and the New Practice of

Radiotherapy: What to Know and Use from a

Decade of Investigation: Kim, J. et al.

Head and Neck Cancers

Intensity-Modulated and Image-Guided

Radiation Therapy for Head and Neck Cancers:

Chu, K.P.-M.; Le, Q.-T.

Delineating Neck Targets for Intensity-Modulated

Radiation Therapy of Head and Neck Cancer:

David, M.B.; Eisbruch, $A$.

Thoracic Cancers

Motion Management and Image Guidance for Thoracic Tumor Radiotherapy: Clinical Treatment Programs: Loo, B.W., Jr. et al.

Breast Cancer

Intensity-Modulated Radiotherapy for Breast Cancer: Advances in Whole and Partial Breast

Treatment: White, J.R.; Meyer, J.L.

\section{Abdominal Cancers}

Image-Guided Radiotherapy Strategies in Upper Gastrointestinal Malignancies: Swaminath, A.; Dawson, L.A.

Lymphomas

Radiotherapy Planning for the Lymphomas:

Expanding Roles for Biologic Imaging: Hoppe, $\boldsymbol{R}$. Prostate Cancer

Image-Guided, Adaptive Radiotherapy of Prostate Cancer: Toward New Standards of Radiotherapy Practice: Kupelian, P.; Meyer, J.L.
Frontiers of Radiation Therapy and Oncology, Vol. 43

Series Editors: Meyer, J.L. (San Francisco, Calif.); Hinkelbein, W. (Berlin)

ISSN 0071-9676 / e-ISSN 1662-3789

IMRT, IGRT, SBRT - Advances in the Treatment Planning and Delivery of Radiotherapy 2nd, revised and extended edition Editor: Meyer, J.L. (San Francisco, Calif.) $X+496$ p., 211 fig., 175 in color, 41 tab., online supplementary material, hard cover, 2011 CHF 198.- / EUR 146.50 / USD 198.00 Prices subject to change

EUR price for Germany, USD price for USA only ISBN 978-3-8055-9680-0 e-ISBN 978-3-8055-9681-7

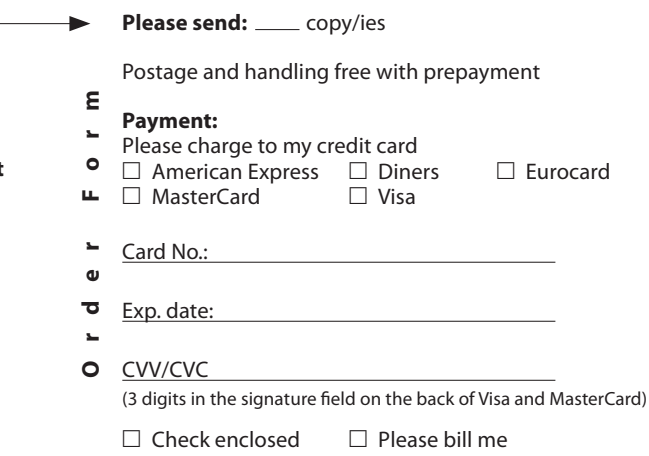

E Payment:

Please charge to my credit card

$\square$ American Express $\square$ Diners $\square$ Eurocard

ᄂ $\square$ MasterCard $\square$ Visa

- Card No.:

$\boldsymbol{\sigma}$

- Exp. date:

- CVV/CVC

( 3 digits in the signature field on the back of Visa and MasterCard)

\section{$\square$ Check enclosed $\square$ Please bill me}

Orders may be placed with any bookshop, subscription agency, directly with the publisher or through a Karger distributor.
SBRT: Stereotactic Body Radiotherapy

SBRT Advances

The Expanding Roles of Stereotactic Body Radiation Therapy and Oligofractionation: Toward a New Practice of Radiotherapy: Kavanagh, B.D. et al.

Stereotactic Body Radiation Therapy: Normal Tissue and Tumor Control Effects with Large Dose per Fraction: Timmerman, R. et al.

Thoracic Cancers

Stereotactic Body Radiation Therapy for Thoracic Cancers: Recommendations for Patient Selection, Setup and Therapy: Timmerman, R. et al.

Gastrointestinal Cancers

Stereotactic Body Radiation Therapy for Gastrointestinal Malignancies: Minn, A.Y. et al.

Genitourinary Cancers

Stereotactic Body Radiotherapy for Prostate Cancer: Current Results of a Phase II Trial: King, $\mathbf{C}$.

\section{Proton Beam Radiotherapy}

Techniques and Technologies

Proton Therapy: Clinical Gains through Current and Future Treatment Programs: Mohan, R.; Bortfeld, $T$.

Medical Applications and Advances

Proton Therapy in the Clinic: DeLaney, T.F.

\section{Fax: +41613061234}

S. Karger AG, P.O. Box, CH-4009 Basel (Switzerland)

E-Mail orders@karger.ch, www.karger.com

Name/Address: 